\title{
DOE/OR/Ci0033--T588
}

\section{DISCREPANCIES IN COMMITTED EFFECTIVE DOSE EQUIVALENTS CALCULATED USING U.S. NUCLEAR REGULATORY COMMISSION REGULATORY GUIDE 8.34 SUGGESTED METHODS*}

\author{
J. R. Windham, ${ }^{\dagger}$ K. J. Kearfott ${ }^{\dagger}$ and F. J. Mis ${ }^{\ddagger}$
}

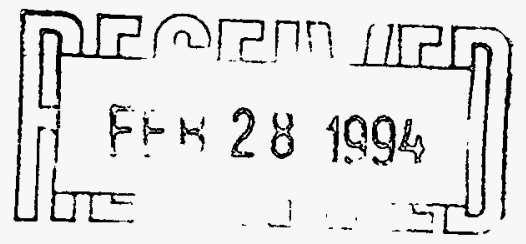

\section{ABSTRACT}

Calculations of Committed Effective Dose Equivalent (CEDE) due to inhalation using four of the five methods suggested in the United States Nuclear Regulatory Commission Regulatory Guide 8.34 (1992) were performed to determine if any significant differences in the calculated value of the CEDE exist for typical power plant radionuclides. These four methods included dose conversion factors from the United States Environmental Protection Agency Federal Guidance Report No. 11 (1988), Annual Limit on Intake, Derived Air Concentrations, and weighted Committed Dose Equivalents from ICRP Publication 30 (1979). Out of sixty-eight radionuclides included, forty-eight demonstrated significant differences of $20 \%$ or greater in the calculated CEDE values for the four methods used. The differences in calculated values for the CEDE can be explained by the varied use of the $10 \%$ Rule and by rounding of tabulated values for ALIs and DACs to one significant digit.

*(Research for this paper was performed under appointment to the Applied Health Physics

Fellowship administered by Oak Ridge Institute for Science and Education for the U.S.

Department of Energy).

'Health Physics Program; The George W. Woodruff School Of Mechanical Engineering, Georgia Institute of Technology, Atlanta, GA 30332-0405; ₹Ginna Nuclear Generating

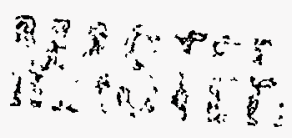




\section{DISCLAIMER}

Portions of this document may be illegible in electronic image products. Images are produced from the best available original document. 
Station, 1503 Lake Road, Ontario, NY 14519.

\section{DISCLAIMER}

This report was prepared as an account of work sponsored by an agency of the United States Government. Neither the United States Government nor any agency thereof, nor any of their employees, makes any warranty, express or implied, or assumes any legal liability or responsibility for the accuracy, completeness, or usefulness of any information, apparatus, product, or process disclosed, or represents that its use would not infringe privately owned rights. Reference herein to any specific commercial product, process, or service by trade name, trademark, manufacturer, or otherwise does not necessarily constitute or imply its endorsement, recommendation, or favoring by the United States Government or any agency thereof. The views and opinions of authors expressed herein do not necessarily state or reflect those of the United States Government or any agency thereof. 


\section{INTRODUCTION}

According to the United States Nuclear Regulatory Commission (NRC) Regulatory Guide 8.34, there are at least five acceptable methods of calculating Committed Effective Dose Equivalent (CEDE) due to inhalation of radionuclides. In Regulatory Guide 8.34, the NRC describes the CEDE as the 50-y effective dose equivalent due to internally deposited radionuclides with the unit of Sievert (Sv) or rem (NRC 1992a). The CEDE is obtained by summing the weighted committed dose equivalents $(\mathrm{CDE})$ for each organ or tissue. The five methods that are given in Regulatory Guide 8.34 for calculating the CEDE are the use of EPA Federal Guidance Report No. 11, Annual Limit on Intake (ALI) from the revised 10 CFR Part 20, Derived Air Concentrations (DAC) from the revised 10 CFR Part 20, International Commission on Radiological Protection (ICRP) Publication 30, and individual or material specific information (NRC 1992a).

The EPA Federal Guidance Report No. 11 lists exposure-to-dose conversion factors for inhalation which may be used to calculate the CEDE (Eckerman et al.). The conversion factor is in units of CEDE per unit activity $\left.(\mathrm{Sv} \mathrm{Bq})^{-1}\right)$. The CEDE is then calculated by $\mathrm{H}_{\mathrm{i}, \mathrm{E}}$ $=\mathrm{CEDE}$ per unit activity $\left(\mathrm{Sv} \mathrm{Bq}^{-1}\right) \times A(\mathrm{~Bq})$, where $\mathrm{H}_{\mathrm{i}, \mathrm{E}}$ is the CEDE for radionuclide $\mathrm{i}$ in Sv and $A$ is the estimated activity of inhaled radionuclide i (NRC 1992a). The conversion factors listed in the EPA Federal Guidance Report No. 11 are based on the metabolic models in the International Commission on Radiological Protection (ICRP) Publication 30 and conform to the dose limits in the 1987 EPA Federal Guidance Report No. 11 of 0.05 Sv per year (Eckerman et al. 1988).

The second method for calculating the CEDE given in Regulatory Guide 8.34 uses 
ALI values that have been tabulated for individual radionuclides in the revised 10 CFR Part 20 (NRC 1992b). Using the estimated activity of the inhaled radionuclide, the CEDE may be calculated by $\mathrm{H}_{\mathrm{i}, \mathrm{E}}=0.05 \times A_{\mathrm{i}} \times\left(\mathrm{ALI}_{\mathrm{i}, \mathrm{E}}\right)^{-1}$, where $\mathrm{H}_{\mathrm{i}, \mathrm{E}}$ is the CEDE for radionuclide $\mathrm{i}$ (Sv), $A_{\mathrm{i}}$ is the activity of inhaled radionuclide $\mathrm{i}(\mathrm{Bq}), \mathrm{ALI}_{\mathrm{i}, \mathrm{E}}$ is the tabulated ALI value due to inhalation for radionuclide $\mathrm{i}(\mathrm{Bq})$ from 10 CFR Part 20, and 0.05 is the CEDE (Sv) from the intake of 1 ALI (NRC 1992a). The tabulated values for ALIs are based on a CEDE of 0.05 Sv due to stochastic effects or $0.5 \mathrm{~Sv}$ due to non-stochastic effects, whichever is more limiting.

The third method given in the NRC Regulatory Guide 8.34 for determining the CEDE is the use of Derived Air Concentrations (DAC) that are tabulated for individual radionuclides in the revised 10 CFR Part 20 (NRC 1992b). Using the estimated activity of the inhaled radionuclide, the CEDE may be calculated using $\mathrm{H}_{\mathrm{i}, \mathrm{E}}=0.05 \times \mathrm{C}_{\mathrm{i}} \times \mathrm{t} \times 2000^{-}$ ${ }^{1} \times\left(\mathrm{DAC}_{\mathrm{i}}\right)^{-1}$ where $\mathrm{H}_{\mathrm{i}, \mathrm{E}}$ is the CEDE for radionuclide $\mathrm{i}, \mathrm{C}_{\mathrm{i}}$ is the concentration of inhaled radionuclide $\mathrm{i}\left(\mathrm{Bq} \mathrm{m}^{-3}\right), \mathrm{t}$ is the time of exposure in hours, 2000 is the number of hours in a work year, $\mathrm{DAC}_{\mathrm{i}}$ is the tabulated $\mathrm{DAC}$ based on corresponding $\mathrm{ALI}$ for radionuclide $\mathrm{i}\left(\mathrm{Bq} \mathrm{m}^{-}\right.$ ${ }^{3}$ ), and 0.05 is the CEDE (Sv) resulting from the intake of $1 \mathrm{ALI}$ or $2000 \mathrm{DAC}$-hours (NRC 1992a).

The fourth method given in the NRC Regulatory Guide 8.34 for determining the CEDE is the use of weighted CDE per unit activity for inhalation from ICRP Publication 30 and supplements. The weighted CDE per unit activity for inhalation published in ICRP Publication 30 and supplements is given for an individual organ or tissue; all organ/tissue values must be summed to obtain the $\mathrm{CEDE}$ per unit activity $\left(\mathrm{Sv} \mathrm{Bq}{ }^{-1}\right)$ used to calculate the 
CEDE. Using the estimated activity of the inhaled radionuclide, the CEDE may be calculated by $\mathrm{H}_{\mathrm{i}, \mathrm{E}}=\Sigma$ (weighted $\mathrm{CDE}$ per unit activity $\left.\left[\mathrm{Sv} \mathrm{Bq}{ }^{-1}\right]\right) \times A(\mathrm{~Bq})$, where $\mathrm{H}_{\mathrm{i}, \mathrm{E}}$ is the CEDE for radionuclide $\mathrm{i}$, and $A$ is the estimated activity of inhaled radionuclide $\mathrm{i}$ (NRC 1992a).

The fifth method given in NRC Regulatory Guide 8.34 for calculating the CEDE is the use of individual or material-specific information. This method involves the physical and biochemical properties of individual radionuclides that have been inhaled. If a better calculation of the CEDE may be obtained by using new or improved data about physical and biochemical properties of radionuclides than that used in other documents, then this information may be used to calculate the CEDE. In the Regulatory Guide 8.34, the NRC comments on the amount of work that is necessary to calculate the CEDE compared to the other four methods and suggests that this method may be most useful in calculating the CEDE in the case of accidental large overexposures (NRC 1992a).

The exposure-to-dose conversion factors given in EPA Federal Guidance Report No. 11, ALIs and DACs given in 10 CFR Part 20, and weighted CDE per unit activity given in ICRP Publication 30 and supplements are listed according to lung clearance classifications. The clearance classifications are given as "D" for day, "W" for week, and " $\mathrm{Y}$ " for year. The " $D$ " classification represents materials that remain in the lung with a half-life of less than 10 days, the "W" classification represents materials that remain in the lung with a half-life of 10 to 100 days, and the " $Y$ " classification represents materials that remain in the lung with a half-life of greater than 100 days (ICRP 1979).

In this report, only the first four methods accepted by the NRC will be used to 
calculate CEDEs for typical power plant radionuclides. These methods include the use of the EPA Federal Guidance Report No. 11, ALI, DAC, and ICRP Publication 30. The method from NRC Regulatory Guide 8.34 for calculating the CEDE using individual or material specific information will not be performed since such exposures represent special cases. This report will demonstrate the problems associated with determining the CEDE by providing example calculations of the CEDE and technical reasons for these problems.

\section{MATERIALS AND METHODS}

A list of radionuclides that nuclear power plants should be concerned with for control of internal doses has been compiled in Table 1. This list was compiled from Institute of Nuclear Power Operations Document 88-010 (INPO 1988) and from the Health Physics and Radiological Health Handbook (Shleien 1992). Also in Table 1 is the exposure-to-dose conversion factor from EPA Federal Guidance Report No. 11, the ALI from the revised 10 CFR Part 20, the DAC from the revised 10 CFR Part 20, the sum of the weighted CDE's from ICRP Publication 30, and activity to be considered for that radionuclide. Table 1 also notes which lung clearance classification was used in calculating the CEDEs for that radionuclide.

The activities listed in Table 1 were chosen so that the CEDE for that radionuclide would be equal to $10 \%$ of $0.05 \mathrm{~Sv}$. Since the monitoring for intake of radionuclides is required if the intake will exceed $10 \%$ of the ALI, a CEDE of $0.005 \mathrm{~Sv}$ is obtained from the intake of $10 \%$ of the ALI (NRC 1992b). Using the exposure-to-dose conversion factor from 
the EPA Federal Guidance Report No. 11, the activity used for radionuclide $\mathrm{i}$ can be calculated by dividing $10 \%$ of $0.05 \mathrm{~Sv}$, or $0.005 \mathrm{~Sv}$, by the exposure-to-dose conversion factor for radionuclide i from EPA Federal Guidance Report No. 11. This is the activity that would represent a CEDE of $0.005 \mathrm{~Sv}$ using this method.

The values listed for ALIs and DACs in the revised 10 CFR Part 20 are presented in units of $\mu \mathrm{Ci}$ and $\mu \mathrm{Ci} \mathrm{mL} \mathrm{mL}^{-1}$, respectively. The $\mu \mathrm{Ci}$ value for the $\mathrm{ALI}$ was converted to $\mathrm{SI}$

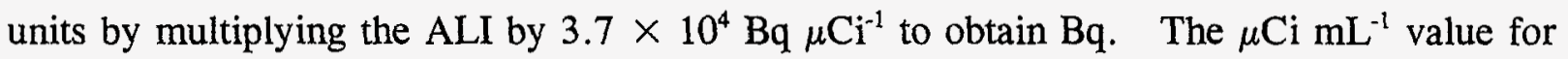
the DAC was converted by multiplying the $\mathrm{DAC}$ by $3.7 \times 10^{10} \mathrm{~Bq} \mathrm{~m}^{-3} \mu \mathrm{Ci}^{-1} \mathrm{~mL}$ to obtain $\mathrm{Bq}$ $\mathrm{m}^{-3}$. When the ALI and DAC were converted from conventional units to SI units, both were rounded to three significant digits to reduce rounding error from the conversion in the calculated values for the CEDE. When calculating the CEDE using the method involving the DAC, the time of exposure was treated as one working year or 2000 working hours. The concentration of inhaled radionuclide is the activity in Bq divided by $2.4 \times 10^{3} \mathrm{~m}^{3}$ which is the amount of air breathed by a worker in one working year (NRC 1992a).

In the list of radionuclides in Table 1 , there were a number of radionuclides that had ALIs based on the non-stochastic limit of $0.50 \mathrm{~Sv}$. For these radionuclides, the nonstochastic $\mathrm{CDE}$ of $0.5 \mathrm{~Sv}$ to a single organ or tissue was exceeded before the stochastic CEDE of 0.05 Sv was exceeded. The radionuclides which demonstrated the ALI being restricted by the nonstochastic ALI were ${ }^{131 \mathrm{~m}} \mathrm{Te},{ }^{132} \mathrm{Te},{ }^{134} \mathrm{Te},{ }^{239} \mathrm{Pu},{ }^{240} \mathrm{Pu},{ }^{241} \mathrm{Pu},{ }^{241} \mathrm{Am},{ }^{242} \mathrm{Cm}$, and ${ }^{244} \mathrm{Cm}$. The DACs for these radionuclides were calculated by dividing the stochastic ALI by $2.4 \times$ $10^{3} \mathrm{~m}^{3}$ (NRC 1992a). 


\section{RESULTS}

Table 2 lists the calculated values of the CEDE using EPA Federal Guidance Report No. 11, ALIs, DACs, and ICRP Publication 30 for the inhaled radionuclides in Table 1 with which nuclear power plants should be concerned for controlling internal doses. Of the 68 radionuclides that were considered, 26 showed differences of $20 \%$ or greater between the CEDE calculated using the EPA Federal Report No. 11 and that calculated using the ALI. Twenty-four of the 68 radionuclides considered showed differences of $20 \%$ between the CEDE calculated using EPA Federal Guidance Report No. 11 and that calculated using the DAC. A comparison between the CEDE calculated using the ALI from the revised 10 CFR Part 20 and the DAC from the revised 10 CFR Part 20 for the 68 radionuclides considered demonstrate that 31 had a difference of $20 \%$ or greater. Eleven of the 68 radionuclides considered showed differences of $20 \%$ or greater between the CEDE calculated using the EPA Federal Guidance Report No. 11 and that calculated using the weighted CDE from ICRP Publication 30.

It should be noted that the CEDE calculated using the EPA Federal Report No. 11 and the ALI for ${ }^{3} \mathrm{H}$ agree within $2 \%$. However, the calculated values for the CEDE using the EPA Federal Guidance Report No. 11 and the DAC from 10 CFR Part 20 for ${ }^{3} \mathrm{H}$ differ by $48 \%$. The calculated values for the CEDE using the ALI and DAC differ by $50 \%$. In the case for tritium, the tabulated value for the DAC takes into account the intake of ${ }^{3} \mathrm{H}$ by absorption through the skin as well as by inhalation. The tabulated value for the ALI from 10 CFR Part 20 for ${ }^{3} \mathrm{H}$ only accounts for the intake due to inhalation thus explaining the noted difference. 


\section{DISCUSSION}

To begin the explanation of the differences in the calculated values of the CEDE for the radionuclides listed in Table 2 , it is necessary to realize that the tabulated values for the conversion factors from EPA Federal Report No. 11 are based on the metabolic modeling of ICRP Publication 30. The ALIs and DACs from 10 CFR Part 20 are based on tabulated values of the weighted CDE per unit activity from ICRP Publication 30. However, the weighted CDE per unit activity values in ICRP Publication 30 and supplements follow the $10 \%$ Rule which states that "a tissue is deemed to be irradiated to a significant extent if for that tissue the weighted value of the CDE per unit intake is greater than $10 \%$ of the maximum weighted value of CDE per unit intake in any tissue" (ICRP 1979). If a tissue does not receive $10 \%$ of the maximum committed dose equivalent to a tissue then that tissue is not included in the tabulated values of the weighted CDE per unit activity in ICRP Publication 30 and supplements. The EPA Federal Guidance Report No. 11 does not follow the $10 \%$ Rule. Therefore, for radionuclides for which the $10 \%$ Rule is applied in the ICRP publication, the conversion factor should be less than the same conversion factor in the EPA Federal Guidance Report No. 11.

An example. in which the exposure-to-dose conversion factor in the EPA Federal Guidance Report No. 11 and the weighted CDE per unit activity from ICRP Publication 30 and supplements agree can be seen in Table 3, where the CDE per unit activity, weighting factors, and the weighted CDE per unit activity for ${ }^{86} \mathrm{Rb}$ from ICRP Publication 30 and supplements are listed for the typical organs and tissues of interest. The sum of the weighted CDE per unit activity, the CEDE per unit activity, from ICRP Publication 30 is $1.79 \times 10^{-9}$ 
Sv Bq ${ }^{-1}$. The CEDE per unit activity reported in EPA Federal Report No. 11 is also $1.79 \times$ $10^{-9} \mathrm{~Sv} \mathrm{~Bq}{ }^{-1}$. Therefore, the calculated value for the CEDE using the ALI calculated from the CEDE per unit activity in ICRP Publication 30 for ${ }^{86} \mathrm{Rb}$ should agree with the calculated value for the CEDE using the CEDE per unit activity from the EPA Federal Guidance Report No. 11. From Table 2, the CEDE calculated using the EPA Federal Guidance Report No. 11 is $5.00 \mathrm{mSv}$ while the CEDE calculated using the ALI from 10 CFR Part 20 is $4.72 \mathrm{mSv}$, agreeing within $6 \%$. Also, since the DAC for ${ }^{86} \mathrm{Rb}$ is determined by ușing the ALI for ${ }^{86} \mathrm{Rb}$, the calculated values of the CEDE using the DAC should be in agreement. The calculated CEDE for ${ }^{86} \mathrm{Rb}$ from Table 2 is $5.24 \mathrm{mSv}$, agreeing within $5 \%$ of the CEDE calculated using the EPA Federal Guidance Report No.11 and within $11 \%$ of the CEDE calculated using the ALI. From Table 2, the CEDE calculated using ICRP Publication 30 is $5.00 \mathrm{mSv}$. This value is in direct agreement with the CEDE calculated using EPA Federal Guidance Report No. 11. This is a case when the $10 \%$ Rule used in ICRP Publication 30 does not exclude any of the specific organs or tissues of interest and the calculated values for the CEDE agree for all three methods.

An example where the $10 \%$ Rule causes disagreement between the calculated CEDE using the EPA Federal Guidance Report No. 11 and the ALI is demonstrated in Table 4. The CDE per unit activity, weighting factors, and weighted CDE per unit activity from ICRP Publication 30 for ${ }^{59} \mathrm{Fe}$ are given for specific organs of interest in Table 4 . The sum of the weighted CDE per unit activity, the CEDE per unit activity, from ICRP Publication 30 is $2.69 \times 10^{-9} \mathrm{~Sv} \mathrm{~Bq}^{-1}$. The CEDE per unit activity from the EPA Federal Guidance Report No. 11 is $3.30 \times 10^{-9} \mathrm{~Sv} \mathrm{~Bq}^{-1}$. The difference between these two values for ${ }^{59} \mathrm{Fe}$ is $20 \%$, 
which introduces a $20 \%$ difference between the calculation of the CEDE by the EPA Federal Guidance Report No. 11 and that by the ALI. The calculated value of the CEDE using the EPA Federal Guidance Report No. 11 is $5.00 \mathrm{mSv}$ while the calculated value of the CEDE using the ALI is $4.10 \mathrm{mSv}$. These two calculated values of the CEDE for ${ }^{59} \mathrm{Fe}$ have a difference of $20 \%$. From Table 2, the CEDE for ${ }^{59} \mathrm{Fe}$ calculated using ICRP Publication 30 is $4.08 \mathrm{mSv}$. This value has a difference of $20 \%$ from the CEDE calculated using EPA Federal Guidance Report No. 11. This example demonstrates how excluding organs or tissues using the $10 \%$ Rule can cause a significant difference in calculated values of the CEDE.

In the revised 10 CFR Part 20 (NRC 1992b), the tabulated values for ALIs and DACs are reported to only one significant digit. Rounding calculated values for ALIs and DACs to one significant digit as is done in 10 CFR Part 20 can cause significant differences between calculated values of the CEDE compared to a calculated CEDE using the EPA Federal Guidance Report No. 11. An example of when rounding causes a significant difference is seen in the calculation of CEDE for ${ }^{137} \mathrm{Cs}$. From ICRP Publication 30 and supplements, the CEDE per unit activity is $8.70 \times 10^{-9} \mathrm{~Sv} \mathrm{~Bq}^{-1}$ while the CEDE per unit activity from EPA Federal Guidance Report No. 11 is $8.63 \times 10^{-9} \mathrm{~Sv} \mathrm{~Bq}{ }^{-1}$. Since the ALI from 10 CFR Part 20 is calculated using the CEDE per unit activity from ICRP Publication 30 and supplements and since both of the CEDEs' per unit activity just given for ${ }^{137} \mathrm{Cs}$ agree within $4 \%$, the calculated values of the CEDE using EPA Federal Guidance Report No. 11 and the ALI should agree within $4 \%$. However, the percent difference between the calculated values of the CEDE using the EPA Federal Guidance Report No. 11 and the ALI from 10 CFR Part 
20 is $24 \%$.

Examining the calculation of the ALI using the CEDE per unit activity in ICRP Publication 30 and supplements will demonstrate why this difference of $24 \%$ exists. Using the CEDE per unit activity from ICRP Publication 30 and supplements for ${ }^{137} \mathrm{Cs}$ to calculate the ALI, a value of $5.75 \times 10^{6} \mathrm{~Bq}(155 \mu \mathrm{Ci})$ is obtained. The ALI for ${ }^{137} \mathrm{Cs}$ listed in 10 CFR Part 20 is $7.40 \times 10^{6} \mathrm{~Bq}(200 \mu \mathrm{Ci})$. The percent difference between the tabulated ALI for ${ }^{137} \mathrm{Cs}$ from $10 \mathrm{CFR}$ Part 20 and the calculated value of the ALI from the CEDE per unit activity from ICRP Publication 30 and supplements is $25 \%$. This explains the difference of $24 \%$ between the calculated values for the CEDE using the EPA Federal Guidance Report No. 11 and the ALI from 10 CFR Part 20.

Similar significant differences due to rounding are also evident in the calculations of the CEDE using the DAC from 10 CFR Part 20 compared to calculated values of the CEDE using the EPA Federal Guidance Report No. 11 and the ALI from 10 CFR Part 20. An example of this is seen in the calculated values of the CEDE for ${ }^{55} \mathrm{Fe}$. From Table 2, there is a difference of $7 \%$ between the calculated value of the CEDE for ${ }^{55} \mathrm{Fe}$ using the EPA Federal Guidance Report No. 11 and the ALI from 10 CFR Part 20 while there is a difference of $25 \%$ between the calculated value of the CEDE for ${ }^{55} \mathrm{Fe}$ using the EPA Federal Guidance Report No. 11 and the DAC from the revised 10 CFR Part 20. Also from Table 2 , there is a difference of $20 \%$ between the calculated value of the CEDE for ${ }^{55} \mathrm{Fe}$ using the ALI and DAC from 10 CFR Part 20.

The difference of $20 \%$ between the calculated values of the CEDE for ${ }^{55} \mathrm{Fe}$ using the ALI and DAC from the revised 10 CFR Part 20 is quite significant considering that the DAC 
is calculated using the ALI from the revised 10 CFR Part 20. The values for the DACs listed in the revised 10 CFR Part 20 are calculated by dividing the ALI by the amount of air breathed by a worker in one work year, $2.4 \times 10^{3} \mathrm{~m}^{3}\left(2.4 \times 10^{9} \mathrm{~mL}\right)(\mathrm{NRC} 1992 \mathrm{a})$. From Table 1 , the ALI for ${ }^{55} \mathrm{Fe}$ given in the revised $10 \mathrm{CFR}$ Part 20 is $1.48 \times 10^{6} \mathrm{~Bq}(4000 \mu \mathrm{Ci})$ while the DAC given in the revised 10 CFR Part 20 for ${ }^{55} \mathrm{Fe}$ is $7.40 \times 10^{4} \mathrm{~Bq} \mathrm{~m}^{-3}\left(2 \times 10^{-6}\right.$ $\mu \mathrm{Ci} \mathrm{mL}{ }^{-1}$ ). Using the ALI given for ${ }^{55} \mathrm{Fe}$ in the revised $10 \mathrm{CFR}$ Part 20 , the DAC is calculated to be $6.17 \times 10^{4} \mathrm{~Bq} \mathrm{~m}^{-3}\left(1.67 \times 10^{-6} \mu \mathrm{Ci} \mathrm{mL}^{-1}\right)$. The difference between the tabulated value for the DAC in the revised 10 CFR Part 20 and the calculated value for the DAC using the ALI is $20 \%$. Rounding the calculated DACs in the revised 10 CFR Part 20 has introduced a difference of $20 \%$ between the calculated value for the DAC and the tabulated DAC listed in the revised 10 CFR Part 20. This explains the differences between the calculated values of the CEDE for ${ }^{55} \mathrm{Fe}$ using the EPA Federal Guidance Report No. 11 with the DAC from the revised 10 CFR Part 20 and the ALI from the revised 10 CFR Part 20 compared with the DAC from the revised 10 CFR Part 20.

A list of the 47 radionuclides that demonstrated a difference of $20 \%$ or greater in the calculations of the CEDE between either the EPA Federal Guidance Report No. 11 and the ALI, between the EPA Federal Guidance Report No. 11 and the DAC from the revised 10 CFR Part 20, between the ALI from the revised 10 CFR Part 20 and the DAC from the revised 10 CFR Part 20, or between the EPA Federal Guidance Report No. 11 and the weighted CDE from ICRP Publication 30 has been compiled in Table 5. The reasons for the differences of $20 \%$ or greater have been designated as being due to either the $10 \%$ Rule, rounding, or both. 


\section{CONCLUSIONS}

The NRC in Regulatory Guide 8.34 (1992a) has given four methods out of five to calculate the CEDE that are based on ICRP Publication 30 and supplements: the EPA Federal Guidance Report No. 11 (1988), ALIs from the revised 10 CFR Part 20 (1992b), DACs from the revised 10 CFR Part 20 (1992b), and weighted CDE from ICRP Publication 30 (1979). However, these four methods do not always give the same results in the calculation of the CEDE. The differences in the calculations of the CEDE for different methods can be attributed to constraints in using the $10 \%$ Rule, in rounding tabulated values to one significant digit, in combinations of the $10 \%$ Rule and rounding, and in the lack of consideration of absorption through the skin in the case of ${ }^{3} \mathrm{H}$.

In "Implementation of 10 CFR 20: Potential Impacts on Internal Dose Assessment Programs", Poston and Poston (1992) discuss problems associated with internal dosimetry using the same methods as used in this report. Their explanation for the problems are given as unit conversions and round-off errors. They discuss the use of the "Ten Percent" rule and conclude that "there are no meaningful differences between dose conversion factors in EPA Federal Guidance Report No. 11 and ICRP Publication 30" (Poston and Poston, 1992). However, this report has demonstrated that the use of the "Ten Percent" rule does impose problems when assessing CEDE for an uptake through inhalation of radionuclides.

In this report, only one lung clearance classification was considered for each radionuclide. However, from the list of radionuclides used in this report, calculations of the CEDE were performed for all three of the clearance classifications and the differences of 
$20 \%$ or greater did not occur for just one clearance classification. Therefore, since the differences in the calculations of the CEDE between the four methods considered in this report are not dependent on clearance classifications, it is expected that there will be significant differences in the calculated values for the CEDE between the four methods for all of the clearance classifications given for the radionuclides. The reasons for the significant differences between the calculated values of the CEDE are use of the $10 \%$ Rule as done in the ICRP Publication 30 and supplements and the degree to which values for ALIs and DACs reported in the revised 10 CFR Part 20 (NRC 1992b) for that individual clearance classification are rounded.

In this report, the only intake of radionuclides considered was through inhalation. In Regulatory Guide 8.34, the NRC also lists four methods for calculating the CEDE due to ingestion. The four methods for calculating the CEDE due to ingestion are the use of CEDE per unit activity due to ingestion from EPA Federal Guidance Report No. 11, stochastic ingestion ALIs from the revised 10 CFR Part 20, weighted CDE per unit activity for oral intake from ICRP Publication 30, and the use of individual or material-specific information due to ingestion (NRC 1992a). Since the ICRP Publication 30 and supplements use the 10\% Rule for ingestion as well as inhalation, and 10 CFR Part 20 (NRC 1992b) lists ALIs due to ingestion to only one significant digit, it is expected that calculations of the CEDE due to ingestion will also exhibit significant differences for the same reasons that apply to the calculations of the CEDE due to inhalation.

Trying to determine which method out of the five methods accepted by the NRC in Regulatory Guide 8.34 is best for calculating the CEDE is difficult. One recommendation to 
facilities having to meet the requirements in Regulatory Guide 8.34 is to use the same method for all calculations of the CEDE; that is, avoid different methods for different radionuclides. Furthermore, since the EPA Federal Guidance Report No. 11 takes into account the dose to all organs and tissues and does not exclude an organ or tissue that does not meet the $10 \%$ Rule, it is recommended to facilities that the calculation of the CEDE using the EPA Federal Guidance Report No. 11 be the method used until the NRC reevaluates Regulatory Guide 8.34 and offers guidance in choosing methods of calculating the CEDE that give the same result. 


\section{REFERENCES}

Eckerman, K. F.; Wolbarst, A. B.; Richardson, A. B. C. Limiting values of radionuclide intake and air concentration and dose conversion factors for inhalation, submersion, and ingestion, Oak Ridge, TN: Environmental Protection Agency: Federal Guidance Report No. 11 (EPA 520/1-8-020); 1988.

Institute of Nuclear Power Operations. Guidelines for radiation protection at nuclear facilities, Atlanta, GA: INPO; Document 88-010; May 1988.

International Commission on Radiological Protection. Limits for intakes of radionuclides by workers. Oxford: Pergamon Press: Publication 30 and Supplements ICRP; Ann. ICRP 2(3/4): 1979.

Poston, John W., Jr.; John W. Poston, Sr. Implementation of 10 CFR 20: Potential Impacts on Internal Dose Assessment Programs. Radiation Protection Management Volume 9, No. 5: September/October 1992.

Shleien, Bernard, ed. Health physics \& radiological health handbook. Silver Spring, MD: Scinta, Inc: 1992.

United States Nuclear Regulatory Commission. Monitoring criteria and methods to calculate occupational radiation doses. Regulatory Guide 8.34; July 1992a.

United States Nuclear Regulatory Commission. Regulations standards for protection against radiation. Title 10 Part 20 Code of Federal Regulations; 1992b. 
Table 1. A list of radionuclides that nuclear power plants should be concerned with for controlling internal doses with corresponding exposure-to-dose conversion factor from EPA Federal Guidance Report No. 11 (EPA 1988), ALI, DAC, CEDE conversion factor from ICRP Publication 30 (1979), and inhaled activity to be used in calculating the CEDE.

\begin{tabular}{|c|c|c|c|c|c|}
\hline Radionuclides & $\begin{array}{l}\text { CEDE exposure-to- } \\
\text { dose conversion } \\
\text { factors }\left(\mathrm{Sv} \mathrm{Bq} \mathrm{q}^{-1}\right)^{\mathrm{a}}\end{array}$ & $\begin{array}{l}\mathrm{ALI} \\
(\mathrm{Bq})^{\mathrm{b}}\end{array}$ & 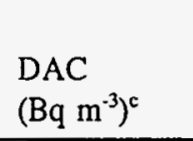 & $\begin{array}{l}\text { CEDE conversion } \\
\text { factors }\left(S \vee \mathrm{Bq}^{-1}\right)^{d}\end{array}$ & $\begin{array}{l}\text { Inhaled } \\
\text { Activity } \\
\text { (Bq) }\end{array}$ \\
\hline${ }^{3} \mathrm{H}^{\mathrm{e}}$ & $1.73^{\circ} \times 10^{-11}$ & $2.96 \times 10^{9}$ & $7.40 \times 10^{5}$ & $1.70 \times 10^{-11}$ & $2.89 \times 10^{8}$ \\
\hline${ }^{14} \mathrm{C}^{f}$ & $6.36 \times 10^{-12}$ & $7.40 \times 10^{9}$ & $3.33 \times 10^{6}$ & * & $7.86 \times 10^{8}$ \\
\hline${ }^{51} \mathrm{Cr}^{1}$ & $9.03 \times 10^{-11}$ & $7.40 \times 10^{8}$ & $2.96 \times 10^{5}$ & $7.11 \times 10^{-11}$ & $5.54 \times 10^{7}$ \\
\hline${ }^{54} \mathrm{Mn}^{\mathrm{h}}$ & $1.81 \times 10^{-9}$ & $2.96 \times 10^{7}$ & $1.11 \times 10^{4}$ & $1.72 \times 10^{-9}$ & $2.76 \times 10^{6}$ \\
\hline${ }^{56} \mathrm{Mn}^{\mathrm{h}}$ & $8.91 \times 10^{-11}$ & $7.40 \times 10^{8}$ & $3.33 \times 10^{5}$ & $6.40 \times 10^{-11}$ & $5.61 \times 10^{7}$ \\
\hline${ }^{58} \mathrm{Co}^{\mathrm{i}}$ & $2.94 \times 10^{-9}$ & $2.59 \times 10^{7}$ & $1.11 \times 10^{4}$ & $1.90 \times 10^{-9}$ & $1.70 \times 10^{6}$ \\
\hline${ }^{60} \mathrm{Co}^{\prime}$ & $5.91 \times 10^{-8}$ & $1.11 \times 10^{6}$ & $3.70 \times 10^{2}$ & $4.10 \times 10^{-8}$ & $8.46 \times 10^{4}$ \\
\hline${ }^{55} \mathrm{Fe}^{\mathrm{h}}$ & $3.61 \times 10^{-10}$ & $1.48 \times 10^{8}$ & $7.40 \times 10^{4}$ & $3.31 \times 10^{-10}$ & $1.39 \times 10^{7}$ \\
\hline${ }^{59} \mathrm{Fe}^{\mathrm{h}}$ & $3.30 \times 10^{-9}$ & $1.85 \times 10^{7}$ & $7.40 \times 10^{3}$ & $2.69 \times 10^{.9}$ & $1.52 \times 10^{6}$ \\
\hline${ }^{65} \mathrm{Zn}^{1}$ & $5.51 \times 10^{-9}$ & $1.11 \times 10^{7}$ & $3.70 \times 10^{3}$ & $5.00 \times 10^{-9}$ & $9.07 \times 10^{5}$ \\
\hline${ }^{84} \mathrm{Br}^{\mathrm{h}}$ & $2.27 \times 10^{-11}$ & $2.22 \times 10^{9}$ & $1.11 \times 10^{6}$ & $2.10 \times 10^{-11}$ & $2.20 \times 10^{8}$ \\
\hline${ }^{86} \mathrm{Rb}^{8}$ & $1.79 \times 10^{-9}$ & $2.96 \times 10^{7}$ & $1.11 \times 10^{4}$ & $1.79 \times 10^{-9}$ & $2.79 \times 10^{6}$ \\
\hline${ }^{88} \mathrm{Rb}^{8}$ & $2.26 \times 10^{-11}$ & $2.22 \times 10^{9}$ & $1.11 \times 10^{6}$ & $2.17 \times 10^{-11}$ & $2.21 \times 10^{6}$ \\
\hline${ }^{89} \mathrm{Rb}^{8}$ & $1.16 \times 10^{-11}$ & $3.70 \times 10^{9}$ & $2.22 \times 10^{6}$ & $1.00 \times 10^{-11}$ & $4.31 \times 10^{8}$ \\
\hline${ }^{89} \mathrm{Sr}^{1}$ & $1.12 \times 10^{-8}$ & $3.70 \times 10^{6}$ & $2.22 \times 10^{3}$ & $1.15 \times 10^{-8}$ & $4.46 \times 10^{5}$ \\
\hline${ }^{90} \mathrm{Sr}^{1}$ & $3.51 \times 10^{-7}$ & $1.48 \times 10^{5}$ & $7.40 \times 10^{1}$ & $3.40 \times 10^{-7}$ & $1.42 \times 10^{4}$ \\
\hline${ }^{91} \mathrm{Sr}^{1}$ & $4.49 \times 10^{-10}$ & $1.48 \times 10^{8}$ & $3.70 \times 10^{4}$ & $3.95 \times 10^{-10}$ & $1.11 \times 10^{7}$ \\
\hline${ }^{2} \mathrm{Sr}^{1}$ & $2.18 \times 10^{-10}$ & $2.59 \times 10^{8}$ & $1.11 \times 10^{5}$ & $2.07 \times 10^{-10}$ & $2.29 \times 10^{7}$ \\
\hline${ }^{90} \mathrm{Y}^{\mathrm{i}}$ & $2.28 \times 10^{-9}$ & $2.22 \times 10^{7}$ & $1.11 \times 10^{4}$ & $2.18 \times 10^{-9}$ & $2.19 \times 10^{6}$ \\
\hline${ }^{91} Y^{\prime}$ & $1.32 \times 10^{-8}$ & $3.70 \times 10^{6}$ & $1.85 \times 10^{3}$ & $1.20 \times 10^{-8}$ & $3.79 \times 10^{5}$ \\
\hline${ }^{2} Y^{\prime}$ & $2.11 \times 10^{-10}$ & $2.96 \times 10^{8}$ & $1.11 \times 10^{5}$ & $1.74 \times 10^{-10}$ & $2.37 \times 10^{7}$ \\
\hline${ }^{95} \mathrm{Zr}^{1}$ & $6.31 \times 10^{-9}$ & $1.11 \times 10^{7}$ & $3.70 \times 10^{3}$ & $4.90 \times 10^{-9}$ & $7.92 \times 10^{5}$ \\
\hline${ }^{95} \mathrm{Nb}^{1}$ & $1.57 \times 10^{-9}$ & $3.70 \times 10^{7}$ & $1.85 \times 10^{4}$ & $1.23 \times 10^{-9}$ & $3.18 \times 10^{6}$ \\
\hline${ }^{99} \mathrm{Mo}^{\mathrm{i}}$ & $1.07 \times 10^{-9}$ & $3.70 \times 10^{7}$ & $2.22 \times 10^{4}$ & $9.90 \times 10^{-10}$ & $4.67 \times 10^{6}$ \\
\hline
\end{tabular}


Table 1 (Continued)

\begin{tabular}{|c|c|c|c|c|c|}
\hline Radionuclides & $\begin{array}{l}\text { CEDE exposure-to- } \\
\text { dose conversion } \\
\text { factors }\left(\mathrm{Sv} \mathrm{Bq}^{-1}\right)^{2}\end{array}$ & $\begin{array}{l}\mathrm{ALI} \\
(\mathrm{Bq})^{\mathrm{b}}\end{array}$ & $\begin{array}{l}\text { DAC } \\
\left(B q m^{-3}\right)^{c}\end{array}$ & 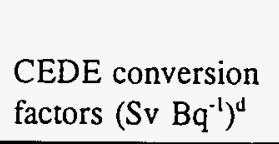 & $\begin{array}{l}\text { Inhaled } \\
\text { Activity } \\
\text { (Bq) }\end{array}$ \\
\hline${ }^{99 m} \mathrm{Tc}^{\mathrm{h}}$ & $7.21 \times 10^{-12}$ & $7.40 \times 10^{6}$ & $3.70 \times 10^{6}$ & $5.67 \times 10^{-12}$ & $6.93 \times 10^{8}$ \\
\hline${ }^{103} \mathrm{Ru}^{\prime}$ & $2.42 \times 10^{-9}$ & $2.22 \times 10^{7}$ & $1.11 \times 10^{4}$ & $2.09 \times 10^{-9}$ & $2.07 \times 10^{6}$ \\
\hline${ }^{105} \mathrm{Ru}^{\prime}$ & $1.23 \times 10^{-10}$ & $3.70 \times 10^{8}$ & $1.85 \times 10^{5}$ & $1.12 \times 10^{-10}$ & $4.07 \times 10^{7}$ \\
\hline${ }^{106} \mathrm{Ru}^{1}$ & $1.29 \times 10^{-7}$ & $3.70 \times 10^{5}$ & $1.85 \times 10^{2}$ & $1.20 \times 10^{-7}$ & $3.88 \times 10^{4}$ \\
\hline${ }^{105} \mathrm{Rh}^{1}$ & $2.58 \times 10^{-10}$ & $2.22 \times 10^{8}$ & $7.40 \times 10^{4}$ & $2.31 \times 10^{-10}$ & $1.94 \times 10^{7}$ \\
\hline${ }^{110 m} \mathrm{Ag}^{\mathrm{i}}$ & $2.17 \times 10^{-8}$ & $3.33 \times 10^{6}$ & $1.48 \times 10^{3}$ & $1.40 \times 10^{-8}$ & $2.30 \times 10^{5}$ \\
\hline${ }^{122} \mathrm{Sb}^{\mathrm{h}}$ & $1.39 \times 10^{.9}$ & $3.70 \times 10^{7}$ & $1.48 \times 10^{4}$ & $1.27 \times 10^{-9}$ & $3.60 \times 10^{6}$ \\
\hline${ }^{124} \mathrm{Sb}^{\mathrm{h}}$ & $6.80 \times 10^{-9}$ & $7.40 \times 10^{6}$ & $3.70 \times 10^{3}$ & $5.65 \times 10^{-9}$ & $7.35 \times 10^{5}$ \\
\hline${ }^{125} \mathrm{Sb}^{\mathrm{h}}$ & $3.30 \times 10^{-9}$ & $1.85 \times 10^{7}$ & $7.40 \times 10^{3}$ & $2.60 \times 10^{-9}$ & $1.52 \times 10^{6}$ \\
\hline${ }^{127} \mathrm{Sb}^{\mathrm{h}}$ & $1.63 \times 10^{-9}$ & $3.33 \times 10^{7}$ & $1.48 \times 10^{4}$ & $1.46 \times 10^{-9}$ & $3.07 \times 10^{6}$ \\
\hline${ }^{129} \mathrm{Sb}^{\mathrm{h}}$ & $1.74 \times 10^{-11}$ & $3.33 \times 10^{8}$ & $1.48 \times 10^{5}$ & $1.57 \times 10^{-10}$ & $2.87 \times 10^{7}$ \\
\hline${ }^{127 \mathrm{~m}} \mathrm{Te}^{\mathrm{h}}$ & $5.81 \times 10^{-9}$ & $1.11 \times 10^{7}$ & $3.70 \times 10^{3}$ & $5.25 \times 10^{-9}$ & $8.61 \times 10^{5}$ \\
\hline${ }^{129} \mathrm{Te}^{\mathrm{h}}$ & $2.09 \times 10^{-11}$ & $2.59 \times 10^{9}$ & $1.11 \times 10^{6}$ & $1.80 \times 10^{-11}$ & $2.39 \times 10^{8}$ \\
\hline${ }^{129 m} \mathrm{Te}^{\mathrm{h}}$ & $6.47 \times 10^{-9}$ & $7.40 \times 10^{6}$ & $3.70 \times 10^{3}$ & $5.46 \times 10^{-9}$ & $7.73 \times 10^{5}$ \\
\hline${ }^{131 m} \mathrm{Te}^{\mathrm{h}}$ & $1.73 \times 10^{-9}$ & $3.33 \times 10^{7}$ & $1.39 \times 10^{4}$ & $1.51 \times 10^{-9}$ & $2.89 \times 10^{6}$ \\
\hline${ }^{132} \mathrm{Te}^{\mathrm{h}}$ & $2.55 \times 10^{-9}$ & $2.22 \times 10^{7}$ & $9.25 \times 10^{3}$ & $2.10 \times 10^{-9}$ & $1.96 \times 10^{6}$ \\
\hline${ }^{134} \mathrm{Te}^{\mathrm{h}}$ & $3.23 \times 10^{-11}$ & $1.85 \times 10^{9}$ & $7.77 \times 10^{5}$ & $2.68 \times 10^{-11}$ & $1.55 \times 10^{8}$ \\
\hline$\left.{ }^{131}\right]^{8}$ & $8.89 \times 10^{-9}$ & $7.40 \times 10^{6}$ & $3.07 \times 10^{3}$ & $8.80 \times 10^{-9}$ & $5.62 \times 10^{5}$ \\
\hline$\left.{ }^{132}\right]^{B}$ & $1.03 \times 10^{-10}$ & $3.70 \times 10^{8}$ & $1.55 \times 10^{5}$ & $9.10 \times 10^{-11}$ & $4.85 \times 10^{7}$ \\
\hline${ }^{133} I^{g}$ & $1.58 \times 10^{-9}$ & $3.33 \times 10^{7}$ & $1.41 \times 10^{4}$ & $1.50 \times 10^{-9}$ & $3.16 \times 10^{6}$ \\
\hline${ }^{134} I^{8}$ & $3.55 \times 10^{-11}$ & $1.85 \times 10^{9}$ & $7.77 \times 10^{5}$ & $2.99 \times 10^{-11}$ & $1.41 \times 10^{8}$ \\
\hline$\left.{ }^{135}\right]^{8}$ & $3.32 \times 10^{-10}$ & $1.48 \times 10^{8}$ & $6.29 \times 10^{4}$ & $3.03 \times 10^{-10}$ & $1.51 \times 10^{7}$ \\
\hline${ }^{134} \mathrm{Cs}^{\mathrm{g}}$ & $1.25 \times 10^{-8}$ & $3.70 \times 10^{6}$ & $1.48 \times 10^{3}$ & $1.25 \times 10^{-8}$ & $4.00 \times 10^{5}$ \\
\hline${ }^{136} \mathrm{Cs}^{\mathrm{g}}$ & $1.98 \times 10^{-9}$ & $2.59 \times 10^{7}$ & $1.11 \times 10^{4}$ & $2.01 \times 10^{-9}$ & $2.53 \times 10^{6}$ \\
\hline${ }^{137} \mathrm{Cs}^{\mathrm{g}}$ & $8.63 \times 10^{-9}$ & $7.40 \times 10^{6}$ & $2.22 \times 10^{3}$ & $8.70 \times 10^{-9}$ & $5.79 \times 10^{5}$ \\
\hline${ }^{138} \mathrm{Cs}^{8}$ & $2.74 \times 10^{-11}$ & $2.22 \times 10^{9}$ & $7.40 \times 10^{5}$ & $2.36 \times 10^{-11}$ & $1.82 \times 10^{8}$ \\
\hline${ }^{140} \mathrm{Ba}^{3}$ & $1.01 \times 10^{-9}$ & $3.70 \times 10^{7}$ & $2.22 \times 10^{4}$ & $9.65 \times 10^{-10}$ & $4.95 \times 10^{6}$ \\
\hline${ }^{140} \mathrm{La}^{\mathrm{h}}$ & $1.31 \times 10^{-9}$ & $3.70 \times 10^{7}$ & $1.85 \times 10^{4}$ & $1.17 \times 10^{-9}$ & $3.82 \times 10^{6}$ \\
\hline${ }^{141} \mathrm{Ce}^{\mathrm{i}}$ & $2.42 \times 10^{-9}$ & $2.22 \times 10^{7}$ & $7.40 \times 10^{3}$ & $2.25 \times 10^{-9}$ & $2.07 \times 10^{6}$ \\
\hline
\end{tabular}


Table 1 (Continued)

\begin{tabular}{llllll}
\hline & $\begin{array}{l}\text { CEDE exposure-to- } \\
\text { dose conversion } \\
\text { factors }(\mathrm{Sv} \mathrm{Bq})^{-1}\end{array}$ & $\begin{array}{l}\mathrm{ALI} \\
(\mathrm{Bq})^{\mathrm{b}}\end{array}$ & $\begin{array}{l}\mathrm{DAC} \\
\left(\mathrm{Bq} \mathrm{m^{-3 }}\right)^{\mathrm{c}}\end{array}$ & $\begin{array}{l}\text { CEDE conversion } \\
\text { factors }(\mathrm{Sv} \mathrm{Bq})^{4}\end{array}$ & $\begin{array}{l}\text { Inhaled } \\
\text { Activity } \\
(\mathrm{Bq})\end{array}$ \\
\hline${ }^{\text {Radionuclides }}$ & & & & & \\
${ }^{143} \mathrm{Ce}^{1}$ & $9.16 \times 10^{-10}$ & $7.40 \times 10^{7}$ & $2.59 \times 10^{4}$ & $8.50 \times 10^{-10}$ & $5.46 \times 10^{6}$ \\
${ }^{144} \mathrm{Ce}^{\prime}$ & $1.01 \times 10^{-7}$ & $3.70 \times 10^{5}$ & $2.22 \times 10^{2}$ & $9.50 \times 10^{-8}$ & $4.95 \times 10^{4}$ \\
${ }^{143} \mathrm{Pr}^{1}$ & $2.19 \times 10^{-9}$ & $2.59 \times 10^{7}$ & $1.11 \times 10^{4}$ & $2.01 \times 10^{-9}$ & $2.28 \times 10^{6}$ \\
${ }^{144} \mathrm{Pr}^{1}$ & $1.17 \times 10^{-11}$ & $3.70 \times 10^{9}$ & $1.85 \times 10^{6}$ & $1.10 \times 10^{-11}$ & $4.27 \times 10^{8}$ \\
${ }^{147} \mathrm{Nd}^{1}$ & $1.85 \times 10^{-9}$ & $2.96 \times 10^{7}$ & $1.48 \times 10^{4}$ & $1.65 \times 10^{-9}$ & $2.70 \times 10^{6}$ \\
${ }^{239} \mathrm{~Np}^{\mathrm{h}}$ & $6.78 \times 10^{-10}$ & $7.40 \times 10^{7}$ & $3.33 \times 10^{4}$ & $5.68 \times 10^{-10}$ & $7.37 \times 10^{6}$ \\
${ }^{238} \mathrm{Pu}^{\mathrm{i}}$ & $7.79 \times 10^{-5}$ & $7.40 \times 10^{2}$ & $2.96 \times 10^{-1}$ & $8.20 \times 10^{-5}$ & $6.42 \times 10^{1}$ \\
${ }^{239} \mathrm{Pu}^{\prime}$ & $8.33 \times 10^{-5}$ & $7.40 \times 10^{2}$ & $3.07 \times 10^{-1}$ & $8.91 \times 10^{-5}$ & $6.00 \times 10^{1}$ \\
${ }^{240} \mathrm{Pu}^{\prime}$ & $8.33 \times 10^{-5}$ & $7.40 \times 10^{2}$ & $3.07 \times 10^{-1}$ & $8.91 \times 10^{-5}$ & $6.00 \times 10^{1}$ \\
${ }^{241} \mathrm{Pu}^{\mathrm{i}}$ & $1.34 \times 10^{-5}$ & $3.70 \times 10^{4}$ & $1.55 \times 10^{1}$ & $1.56 \times 10^{-6}$ & $3.73 \times 10^{3}$ \\
${ }^{241} \mathrm{Am}^{\mathrm{h}}$ & $1.20 \times 10^{-4}$ & $3.70 \times 10^{2}$ & $1.55 \times 10^{-1}$ & $1.41 \times 10^{-4}$ & $4.17 \times 10^{1}$ \\
${ }^{242} \mathrm{Cm}^{\mathrm{h}}$ & $4.67 \times 10^{-6}$ & $1.11 \times 10^{4}$ & $4.63 \times 10^{0}$ & $4.66 \times 10^{-6}$ & $1.07 \times 10^{3}$ \\
${ }^{244} \mathrm{Cm}^{2}$ & $6.70 \times 10^{-5}$ & $7.40 \times 10^{2}$ & $3.07 \times 10^{-1}$ & $7.40 \times 10^{-5}$ & $7.46 \times 10^{1}$ \\
\hline
\end{tabular}

*No CEDE conversion factor from ICRP Publication 30 is given for ${ }^{14} \mathrm{C}$.

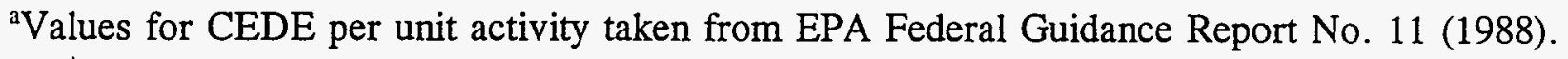

${ }^{b}$ Values for ALI taken from the revised 10 CFR Part 20 (1992b).

${ }^{c}$ Values for DAC taken from the revised 10 CFR Part 20 (1992b).

${ }^{d}$ Values for CEDE per unit activity taken from ICRP Publication 30 (1979).

${ }^{e}$ Lung clearance classification considered for this radionuclide was water vapor.

- 'Lung clearance classification considered for this radionuclide was carbon dioxide.

${ }^{\text {g}}$ Lung clearance classification considered for these radionulcides was day.

${ }^{\mathrm{h}}$ Lung clearance classification considered for these radionuclides was week.

'Lung clearance classification considered for these radionuclides was year. 
Table 2. Calculations of the CEDE using the EPA Federal Guidance Report No. 11 (1988), ALIs from the revised 10 CFR Part 20 (1992b), DACs from 10 CFR Part 20 (1992b), and ICRP Publication 30 (1979) for radionuclides that nuclear power plants should be concerned with for controlling internal doses listed in Table 1.

\begin{tabular}{|c|c|c|c|c|}
\hline \multirow[b]{2}{*}{ Radionuclides } & \multicolumn{4}{|c|}{ Committed effective dose equivalent (mSv) } \\
\hline & $\begin{array}{l}\text { EPA Federal } \\
\text { Report No. } 11\end{array}$ & $\begin{array}{l}10 \text { CFR Part } 20 \\
\text { ALI }\end{array}$ & $\begin{array}{l}10 \text { CFR Part } 20 \\
\text { DAC }\end{array}$ & $\begin{array}{l}\text { ICRP } \\
\text { Publication } 30\end{array}$ \\
\hline${ }^{3} \mathrm{H}$ & 5.00 & 4.88 & 8.14 & 4.91 \\
\hline${ }^{14} \mathrm{C}$ & 5.00 & 5.31 & 4.92 & * \\
\hline${ }^{51} \mathrm{Cr}$ & 5.00 & 3.74 & 3.90 & 3.94 \\
\hline${ }^{54} \mathrm{Mn}$ & 5.00 & 4.67 & 5.18 & 4.75 \\
\hline${ }^{56} \mathrm{Mn}$ & 5.00 & 3.79 & 3.51 & 3.59 \\
\hline${ }^{58} \mathrm{Co}$ & 5.00 & 3.28 & 3.19 & 3.23 \\
\hline${ }^{60} \mathrm{Co}$ & 5.00 & 3.81 & 4.76 & 3.47 \\
\hline${ }^{55} \mathrm{Fe}$ & 5.00 & 4.68 & 3.90 & 4.58 \\
\hline${ }^{59} \mathrm{Fe}$ & 5.00 & 4.10 & 4.27 & 4.08 \\
\hline${ }^{65} \mathrm{Zn}$ & 5.00 & 4.09 & 5.11 & 4.54 \\
\hline${ }^{84} \mathrm{Br}$ & 5.00 & 4.96 & 4.13 & 4.63 \\
\hline${ }^{86} \mathrm{Rb}$ & 5.00 & 4.72 & 5.24 & 5.00 \\
\hline${ }^{88} \mathrm{Rb}$ & 5.00 & 4.98 & 4.15 & 4.80 \\
\hline${ }^{89} \mathrm{Rb}$ & 5.00 & 5.82 & 4.04 & 4.31 \\
\hline${ }^{89} \mathrm{Sr}$ & 5.00 & 6.03 & 4.19 & 5.13 \\
\hline${ }^{90} \mathrm{Sr}$ & 5.00 & 4.81 & 4.01 & 4.84 \\
\hline${ }^{91} \mathrm{Sr}$ & 5.00 & 3.76 & 6.27 & 4.40 \\
\hline${ }^{92} \mathrm{Sr}$ & 5.00 & 4.43 & 4.30 & 4.75 \\
\hline${ }^{90} \mathrm{Y}$ & 5.00 & 4.94 & 4.12 & 4.78 \\
\hline${ }^{91} \mathrm{Y}$ & 5.00 & 5.12 & 4.27 & 4.55 \\
\hline${ }^{92} \mathrm{Y}$ & 5.00 & 4.00 & 4.45 & 4.12 \\
\hline
\end{tabular}


Table 2 (Continued)

\begin{tabular}{|c|c|c|c|c|}
\hline \multirow[b]{2}{*}{ Radionuclides } & \multicolumn{4}{|c|}{ Committed effective dose equivalent (mSv) } \\
\hline & $\begin{array}{l}\text { EPA Federal } \\
\text { Report No. } 11\end{array}$ & $\begin{array}{l}10 \text { CFR Part } 20 \\
\text { ALI }\end{array}$ & $\begin{array}{l}10 \text { CFR Part } 20 \\
\text { DAC }\end{array}$ & $\begin{array}{l}\text { ICRP } \\
\text { Publication } 30\end{array}$ \\
\hline${ }^{95} \mathrm{Zr}$ & 5.00 & 3.57 & 4.46 & 3.88 \\
\hline${ }^{97} \mathrm{Zr}$ & 5.00 & 5.78 & 4.81 & 4.57 \\
\hline${ }^{95} \mathrm{Nb}$ & 5.00 & 4.30 & 3.59 & 3.92 \\
\hline${ }^{99} \mathrm{Mo}$ & 5.00 & 6.31 & 4.39 & 4.63 \\
\hline${ }^{99 \mathrm{~m}} \mathrm{Tc}$ & 5.00 & 4.69 & 3.90 & 3.93 \\
\hline${ }^{103} \mathrm{Ru}$ & 5.00 & 4.65 & 3.88 & 4.32 \\
\hline${ }^{105} \mathrm{Ru}$ & 5.00 & 5.49 & 4.58 & 4.55 \\
\hline${ }^{106} \mathrm{Ru}$ & 5.00 & 5.24 & 4.36 & 4.65 \\
\hline${ }^{105} \mathrm{Rh}$ & 5.00 & 4.36 & 5.46 & 4.48 \\
\hline${ }^{110 \mathrm{~m}} \mathrm{Ag}$ & 5.00 & 3.46 & 3.24 & 3.23 \\
\hline${ }^{122} \mathrm{Sb}$ & 5.00 & 4.86 & 5.06 & 4.57 \\
\hline${ }^{124} \mathrm{Sb}$ & 5.00 & 4.97 & 4.17 & 4.15 \\
\hline${ }^{125} \mathrm{Sb}$ & 5.00 & 4.10 & 4.27 & 3.94 \\
\hline${ }^{127} \mathrm{Sb}$ & 5.00 & 4.61 & 4.32 & 4.48 \\
\hline${ }^{129} \mathrm{Sb}$ & 5.00 & 4.31 & 4.04 & 4.51 \\
\hline${ }^{127} \mathrm{Te}$ & 5.00 & 3.93 & 4.68 & 4.53 \\
\hline${ }^{127 \mathrm{~m}} \mathrm{Te}$ & 5.00 & 3.88 & 4.85 & 4.52 \\
\hline${ }^{129} \mathrm{Te}$ & 5.00 & 4.62 & 4.49 & 4.31 \\
\hline${ }^{129 \mathrm{~m}} \mathrm{Te}$ & 5.00 & 5.22 & 4.35 & 4.22 \\
\hline${ }^{131 \mathrm{~m}} \mathrm{Te}$ & 5.00 & 4.34 & 4.34 & 4.36 \\
\hline${ }^{132} \mathrm{Te}$ & 5.00 & 4.42 & 4.42 & 4.12 \\
\hline${ }^{134} \mathrm{Te}$ & 5.00 & 4.18 & 4.15 & 4.15 \\
\hline${ }^{131} \mathrm{I}$ & 5.00 & 3.80 & 3.82 & 4.95 \\
\hline${ }^{132} \mathrm{I}$ & 5.00 & 6.56 & 6.51 & 4.42 \\
\hline${ }^{133} \mathrm{I}$ & 5.00 & 4.75 & 4.69 & 4.75 \\
\hline${ }^{134} \mathrm{I}$ & 5.00 & 3.81 & 3.78 & 4.21 \\
\hline
\end{tabular}


Table 2 (Continued)

\begin{tabular}{lllll}
\hline & \multicolumn{4}{c}{ Committed effective dose equivalent (mSv) } \\
\cline { 2 - 5 } Radionuclides & $\begin{array}{l}\text { EPA Federal } \\
\text { Report No. 11 }\end{array}$ & 10 CFR Part 20 & 10 CFR Part 20 & ICRP \\
\hline${ }^{135} \mathrm{I}$ & 5.00 & 5.09 & 4.99 & 4.56 \\
${ }^{134} \mathrm{Cs}$ & 5.00 & 5.41 & 5.63 & 5.00 \\
${ }^{136} \mathrm{Cs}$ & 5.00 & 4.88 & 4.74 & 5.08 \\
${ }^{137} \mathrm{Cs}$ & 5.00 & 3.91 & 5.44 & 5.04 \\
${ }^{138} \mathrm{Cs}$ & 5.00 & 4.11 & 5.14 & 4.31 \\
${ }^{140} \mathrm{Ba}$ & 5.00 & 6.69 & 4.65 & 4.78 \\
${ }^{140} \mathrm{La}$ & 5.00 & 5.16 & 4.30 & 4.47 \\
${ }^{141} \mathrm{Ce}$ & 5.00 & 4.65 & 5.82 & 4.65 \\
${ }^{143} \mathrm{Ce}$ & 5.00 & 3.69 & 4.39 & 4.64 \\
${ }^{144} \mathrm{Ce}$ & 5.00 & 6.69 & 4.65 & 4.70 \\
${ }^{143} \mathrm{Pr}$ & 5.00 & 4.41 & 4.29 & 4.59 \\
${ }^{144} \mathrm{Pr}$ & 5.00 & 5.78 & 4.81 & 4.70 \\
${ }^{147} \mathrm{Nd}$ & 5.00 & 4.57 & 3.80 & 4.46 \\
${ }^{239} \mathrm{~Np}$ & 5.00 & 4.98 & 4.61 & 4.19 \\
${ }^{238} \mathrm{Pu}$ & 5.00 & 4.34 & 4.52 & 5.26 \\
${ }^{239} \mathrm{Pu}$ & 5.00 & 4.09 & 4.07 & 5.35 \\
${ }^{240} \mathrm{Pu}$ & 5.00 & 4.06 & 4.07 & 5.35 \\
${ }^{241} \mathrm{Pu}$ & 5.00 & 5.04 & 5.00 & 5.82 \\
${ }^{241} \mathrm{Am}$ & 5.00 & 5.63 & 5.59 & 5.88 \\
${ }^{242} \mathrm{Cm}$ & 5.00 & 4.82 & 4.82 & 4.99 \\
${ }^{244} \mathrm{Cm}$ & 5.00 & 5.04 & 5.06 & 5.52 \\
\hline
\end{tabular}

*No CEDE conversion factor from ICRP Publication 30 (1979) is given for ${ }^{14} \mathrm{C}$. 
Table 3. Example of calculations of the weighted $\mathrm{CDE}\left(\mathrm{w}_{\mathrm{T}} \mathrm{H}_{\mathrm{T} .50}\right)$ for ${ }^{86} \mathrm{Rb}$ from ICRP Publication 30 (1979) and supplements. In this case, the 10\% Rule used in ICRP Publication 30 does not exclude any organs or tissues and the CEDE per unit activity calculated by summing the weighted CDE per unit activity agrees with the CEDE per unit activity listed in EPA Federal Guidance Report No. 11 (1988), $1.79 \times 10^{-9} \mathrm{~Sv} \mathrm{~Bq}^{-1}$.

\begin{tabular}{llll}
\hline Organ/Tissue & $\mathrm{H}_{\mathrm{T}, 50}\left(\times 10^{-9} \mathrm{~Sv} \mathrm{~Bq}^{-1}\right)^{\mathrm{a}}$ & $\mathrm{w}_{\mathrm{T}}{ }^{\mathrm{b}}$ & $\mathrm{w}_{\mathrm{T}} \mathrm{H}_{\mathrm{T}, 50}\left(\times 10^{-9} \mathrm{~Sv} \mathrm{~Bq}^{-1}\right)$ \\
\hline Gonad & 1.3 & 0.25 & 0.33 \\
Breasts & 1.3 & 0.15 & 0.20 \\
R. Marrow & 2.3 & 0.12 & 0.28 \\
Lungs & 3.3 & 0.12 & 0.40 \\
Thyroid & 1.3 & 0.03 & 0.039 \\
Bone Surf. & 4.3 & 0.03 & 0.13 \\
St. Wall & 1.5 & 0.06 & 0.090 \\
LLI Wall & 1.4 & 0.06 & 0.084 \\
Remainder & 1.4 & 0.18 & 0.25 \\
\hline & & \multicolumn{2}{c}{$\sum \mathrm{w}_{\mathrm{T}} \mathrm{H}_{\mathrm{T}, 50}=1.79 \times 10^{-9} \mathrm{~Sv} \mathrm{~Bq}^{-1}$}
\end{tabular}

avalues for CDE per unit activity taken from ICRP Publication 30 (1979) and supplements. bValues for weighting factors taken from ICRP Publication 30 (1979). 
Table 4. Examples of calculations of the weighted $\mathrm{CDE}\left(\mathrm{W}_{\mathrm{T}} \mathrm{H}_{\mathrm{T} .50}\right)$ for ${ }^{59} \mathrm{Fe}$ from ICRP Publication 30 and supplements (1979). In this case, the 10\% Rule used by ICRP Publication 30 excludes some organs and tissues that are included in the calculations of the tabulated CEDE per unit activity listed in EPA Federal Guidance Report No. 11 (1988), $3.30 \times 10^{-9}$ Sv Bq ${ }^{-1}$.

\begin{tabular}{llll}
\hline Organ/Tissue & $\mathrm{H}_{\mathrm{T}, 50}\left(\times 10^{-9} \mathrm{~Sv} \mathrm{~Bq}^{-1}\right)^{\mathrm{a}}$ & $\mathrm{W}_{\mathrm{T}}^{\mathrm{b}}$ & $\mathrm{W}_{\mathrm{T}} \mathrm{H}_{\mathrm{T}, 50}\left(\times 10^{-9} \mathrm{~Sv} \mathrm{~Bq}^{-1}\right)$ \\
\hline Gonads & 1.40 & 0.25 & 0.35 \\
Breasts & 1.30 & 0.15 & 0.19 \\
Lungs & 17.0 & 0.12 & 1.70 \\
LLI Wall & 4.50 & 0.06 & 0.27 \\
Spleen & 2.90 & 0.06 & 0.18 \\
\hline \multicolumn{3}{r}{$\sum \mathrm{W}_{\mathrm{T}} \mathrm{H}_{\mathrm{T}, 50}=2.69 \times 10^{-9} \mathrm{~Sv} \mathrm{~Bq}^{-1}$}
\end{tabular}

${ }^{a}$ Value for CDE per unit activity taken from ICRP Publication 30 and supplements (1979).

${ }^{b}$ Values for weighting factors taken from ICRP Publication 30 (1979). 
Table 5. The list of radionuclides that demonstrated a significant difference of $20 \%$ or greater in calculated of the CEDE either between the EPA Federal Guidance Report No. 11 (1988) and the ALI from the revised 10 CFR Part 20, between the EPA Federal Guidance Report No. 11 (1988) and the DAC from the revised 10 CFR Part 20, or between the ALI from the revised 10 CFR Part 20 and the DAC from the revised 10 CFR Part 20.

\begin{tabular}{|c|c|c|c|c|}
\hline Radionuclides & $\begin{array}{l}\text { EPA FGR No. } 11 \text { vs. } \\
10 \text { CFR } 20 \text { ALI }\end{array}$ & $\begin{array}{l}\text { EPA FGR No.11 vs. } \\
10 \text { CFR } 20 \text { DAC }\end{array}$ & $\begin{array}{l}10 \text { CFR } 20 \text { ALI vs. } \\
10 \text { CFR } 20 \text { DAC }\end{array}$ & $\begin{array}{l}\text { EPA FGR No. } 11 \\
\text { vs. ICRP } 30\end{array}$ \\
\hline${ }^{3} \mathrm{H}$ & . & Absorption & Absorption & \\
\hline${ }^{51} \mathrm{Cr}$ & $10 \%$ Rule & $10 \%$ Rule & & $10 \%$ Rule \\
\hline${ }^{56} \mathrm{Mn}$ & $10 \%$ Rule & $10 \%$ Rule & & $10 \%$ Rule \\
\hline${ }^{58} \mathrm{Co}$ & $10 \%$ Rule & $10 \%$ Rule & & $10 \%$ Rule \\
\hline${ }^{60} \mathrm{Co}$ & $10 \%$ Rule & & Rounding & $10 \%$ Rule \\
\hline${ }^{55} \mathrm{Fe}$ & & Rounding & Rounding & \\
\hline${ }^{59} \mathrm{Fe}$ & $10 \%$ Rule & & & $10 \%$ Rule \\
\hline${ }^{65} \mathrm{Zn}$ & $10 \%$ Rule/Rounding & 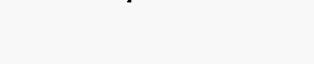 & Rounding & \\
\hline${ }^{84} \mathrm{Br}$ & & Rounding & Rounding & \\
\hline${ }^{88} \mathrm{Rb}$ & & Rounding & Rounding & \\
\hline${ }^{89} \mathrm{Rb}$ & & Rounding & Rounding & \\
\hline${ }^{89} \mathrm{Sr}$ & Rounding & Rounding & Rounding & \\
\hline${ }^{\infty} \mathrm{Sr}$ & & Rounding & Rounding & \\
\hline${ }^{2} \mathrm{Sr}$ & $10 \%$ Rule/Rounding & $10 \%$ Rule/Rounding & Rounding & \\
\hline${ }^{90} \mathrm{Y}$ & & Rounding & Rounding & \\
\hline${ }^{91} Y$ & & & Rounding & \\
\hline${ }^{2} Y$ & $10 \%$ Rule & . & & $10 \%$ Rule \\
\hline${ }^{95} \mathrm{Zr}$ & $10 \%$ Rule & $\cdot$ & Rounding & $10 \%$ Rule \\
\hline${ }^{97} \mathrm{Zr}$ & & & Rounding & \\
\hline${ }^{95} \mathrm{Nb}$ & & Rounding & Rounding & $10 \%$ Rule \\
\hline${ }^{99} \mathrm{Mo}$ & Rounding & & Rounding & \\
\hline${ }^{99 \mathrm{~m}} \mathrm{Tc}$ & & Rounding & Rounding & $10 \%$ Rule \\
\hline
\end{tabular}


Table 5 (Continued)

\begin{tabular}{|c|c|c|c|c|}
\hline Radionuclides & $\begin{array}{l}\text { EPA FGR No. } 11 \text { vs. } \\
10 \text { CFR } 20 \text { ALI }\end{array}$ & $\begin{array}{l}\text { EPA FGR No.11 vs. } \\
10 \text { CFR } 20 \text { DAC }\end{array}$ & $\begin{array}{l}10 \text { CFR } 20 \text { ALI vs. } \\
10 \text { CFR } 20 \text { DAC }\end{array}$ & $\begin{array}{l}\text { EPA FGR No. } 11 \\
\text { vs. ICRP } 30\end{array}$ \\
\hline${ }^{103} \mathrm{Ru}$ & & Rounding & Rounding & \\
\hline${ }^{105} \mathrm{Ru}$ & & & Rounding & \\
\hline${ }^{106} \mathrm{Ru}$ & & & Rounding & \\
\hline${ }^{105} \mathrm{Rh}$ & & & Rounding & \\
\hline${ }^{110 \mathrm{~m}} \mathrm{Ag}$ & $10 \%$ Rule & $10 \%$ Rule & & $10 \%$ Rule \\
\hline${ }^{124} \mathrm{Sb}$ & & Rounding & Rounding & \\
\hline${ }^{125} \mathrm{Sb}$ & $10 \%$ Rule & & & $10 \%$ Rule \\
\hline${ }^{129} \mathrm{Sb}$ & & Rounding & & \\
\hline${ }^{127} \mathrm{Te}$ & $10 \%$ Rule/Rounding & & & $\cdot$ \\
\hline${ }^{127 \mathrm{~m}} \mathrm{Te}$ & $10 \%$ Rule/Rounding & & Rounding & \\
\hline${ }^{129 \mathrm{~m}} \mathrm{Te}$ & & & Rounding & \\
\hline${ }^{134} \mathrm{Te}$ & $10 \%$ Rule & $10 \%$ Rule & & \\
\hline${ }^{131} I$ & Rounding & Rounding & & \\
\hline${ }^{132} \mathrm{I}$ & Rounding & Rounding & & \\
\hline${ }^{134} \mathrm{I}$ & $10 \%$ Rule/Rounding & Rounding & & \\
\hline${ }^{137} \mathrm{Cs}$ & Rounding & & Rounding & \\
\hline${ }^{138} \mathrm{Cs}$ & Rounding & & Rounding & \\
\hline${ }^{140} \mathrm{Ba}$ & Rounding & & Rounding & \\
\hline${ }^{140} \mathrm{La}$ & & & Rounding & \\
\hline${ }^{141} \mathrm{Ce}$ & & & Rounding & \\
\hline${ }^{143} \mathrm{Ce}$ & Rounding & & & \\
\hline${ }^{144} \mathrm{Ce}$ & Rounding & & Rounding & \\
\hline${ }^{144} \mathrm{Pr}$ & & & Rounding & \\
\hline${ }^{147} \mathrm{Nd}$ & & Rounding & Rounding & \\
\hline${ }^{239} \mathrm{Pu}$ & Rounding & Rounding & & \\
\hline${ }^{240} \mathrm{Pu}$ & Rounding & & & \\
\hline
\end{tabular}

